\title{
Isolation, culture, characterization, and osteogenic differentiation of canine endometrial mesenchymal stem cell
}

\author{
A. K. Sahoo, J. K. Das and S. Nayak \\ Department of Veterinary Surgery and Radiology, College of Veterinary Science and Animal Husbandry, OUAT, \\ Bhubaneswar - 751 003, Odisha, India. \\ Corresponding author: A. K. Sahoo, e-mail: aks76vet@gmail.com \\ Co-authors: JKD: drjohndasjajpur@gmail.com, SN: drsnayak.ovc@gmail.com \\ Received: 03-08-2017, Accepted: 04-12-2017, Published online: 30-12-2017
}

doi: 10.14202/vetworld.2017.1533-1541 How to cite this article: Sahoo AK, Das JK, Nayak S (2017) Isolation, culture, characterization, and osteogenic differentiation of canine endometrial mesenchymal stem cell, Veterinary World, 10(12): 1533-1541.

\begin{abstract}
Aim: In this study, the canine endometrium tissue is characterized for its stem cell properties such as adherence to tissue culture plate (plasticity), short population doubling time, serial clonal passaging, long-term culturing properties, stem cell marker expression, and multilineage differentiation potential.
\end{abstract}

Materials and Methods: The present work describes a novel isolation protocol for obtaining mesenchymal stem cells from the uterine endometrium and is compared with cells derived from umbilical cord matrix as a positive control. These cells are clonogenic, can undergo several population doublings in vitro, and can be differentiated to the osteocytes in mature mesenchymal tissues when grown in osteogenic differentiation media as detected by Alizarin Red-S staining.

Results: It is reported for the first time that the cells derived from the canine endometrium (e-multipotent stem cells [MSCs]) were able to differentiate into a heterologous cell type: Osteocytes, thus demonstrating the presence of MSCs. Thus, the endometrium may be told as a potential source of MSCs which can be used for various therapeutic purposes.

Conclusion: The endometrium can be used as a potential source of MSCs, which can be used for various therapeutic purposes.

Keywords: Alizarin Red-S staining, endometrium, mesenchymal stem cell, multipotent stem cells marker, osteogenic differentiation media.

\section{Introduction}

Stem cells are undifferentiated cells defined by their ability at the single-cell level to both self-renewal and differentiate to produce mature progeny cells which include both non-renewing progenitors and terminally differentiating cells. Those have been classified by their developmental potential as totipotent, pluripotent, multipotent, oligopotent, and unipotent [1]. Again, these are also classified as embryonic and adult stem cells as per its origin. The adult stem cells are very difficult to identify in tissues as they are rare, lack in distinguishing morphological features, and the specific adult stem cell markers are currently unavailable. They are also defined by functional properties such as substantial self-renewal, high proliferative potential, and ability to differentiate into one or more lineages [2-4]. The multipotent stem cells (MSCs) were first isolated and characterized from bone marrow [5] and later on from various tissues such as umbilical cord blood [6], adipose

\footnotetext{
Copyright: Sahoo, et al. Open Access. This article is distributed under the terms of the Creative Commons Attribution 4.0 International License (http://creativecommons.org/licenses/by/4.0/), which permits unrestricted use, distribution, and reproduction in any medium, provided you give appropriate credit to the original author(s) and the source, provide a link to the Creative Commons license, and indicate if changes were made. The Creative Commons Public Domain Dedication waiver (http://creativecommons.org/ publicdomain/zero/1.0/) applies to the data made available in this article, unless otherwise stated.
}

tissue [7], amniotic fluid [8], amniotic membrane [9], and peripheral blood [10]. The existence of endometrial mesenchymal stem cell (En-MSCs) population in different species has been demonstrated by different groups in heifer [11], human [12], murine [13], ovine [14], equine [15], and canine [16].

Recently, while looking into the numerous application of stem cells in regenerative medicine as a part of the therapeutic application, its isolation from a readily available source is need of the day which is ethically conducive, plenty available, low cost and still have the multipotent characteristic. The unlimited proliferative and developmental potential of endometrial stem cells offer considerable opportunity for applications in regenerative medicine and tissue engineering.

Till date very little information has been in the literature about canine endometrium derived stem cells. Hence, in this study, attempts have been made to derive the adult stem cells from canine endometrium basing on by their functional properties such as adherence to tissue culture plate, (plasticity), short population doubling time, serial clonal passaging, long-term culturing properties, stem cell marker expression, and multilineage differentiation potential.

\section{Materials and Methods}

\section{Ethical approval}

Although the animal tissues were used in the research study for the harvesting of tissues, it did 
not involve any invasive or inhumane methodology. In fact, sacrificing live animals for harvesting the required tissues were not needed at all. The canine uterus and umbilical cord matrix used in the current research were collected during the routine spaying procedure and cesarean sectioning, for deliveries of the fetuses, respectively, in the Department of Veterinary Surgery and Radiology. The samples were also collected from routine spaying procedures being conducted at Veterinary Polyclinic Saheed Nagar, as Animal Birth Control Program, a flagship program of Fisheries and Animal Resources Development Department (F.A.R.D.), Government of Odisha. Due permission was obtained from the Directorate of Animal husbandry and Veterinary Services for obtaining tissue samples and further analysis in the study. Thus, discarded and disposed of materials collected from these centers were only used for isolating and characterizing stem cells from the tissue samples.

\section{Study design}

Healthy mongrel breed dogs $(n=8, B . w t=14$ $20 \mathrm{~kg}$ ) were used for the study. Applicable institutional and governmental regulations concerning the ethical use of animals were followed during the research. The exteriorized discarded whole uteri were collected through ovariohysterectomy procedure following the standard operative protocol of Animal Welfare Board of India. In the spaying procedure, animals were premedicated intramuscularly with injection atropine $(0.04 \mathrm{mg} / \mathrm{kg})$, injection xylazine $(1.0 \mathrm{mg} / \mathrm{kg})$, and injection ketamine $(5-10 \mathrm{mg} / \mathrm{kg})$ and maintained on ketamine anesthesia intravenously with drip. A total of 12 numbers of samples ( 8 number of the uterus for scrapping and four number of umbilical cord from one caesarian section patient) were collected for experimental design. Maintenance of dogs was done in the kennel of $\mathrm{ABC}$ wing of Veterinary Polyclinic and was released at about 5-7 days after wounds have been healed. Three different transport media, i.e., liquid nitrogen (LN2), phosphate-buffered saline (PBS), and RNAlater $^{\mathrm{TM}}$ stabilizing agents were used for collection and transfer of tissues to the laboratory.

The uterus which was snap frozen in liquid nitrogen was subjected to cryostat sectioning (Leica CM 1850, Germany) and mounted on a charged glass slide. The specimen on a glass slide was air dried, stained as per the protocol for hematoxylin and eosin ( $\mathrm{H}$ and $\mathrm{E}$ ) staining of frozen section, and was observed under light microscope (Leica, Germany). Tissues collected in $1 \times$ PBS were also subjected to paraffin block embedding and sectioning to undergo further $\mathrm{H}$ and $\mathrm{E}$ staining for histological views of three layers of the uterus (perimetrium, myometrium, and endometrium). This was done to confirm that the innermost layers which were scrapped to collect the tissue samples belong to the uterine endometrium containing prospective cells.

\section{Cell isolation and culture}

For isolation and culture of cells, the collected uterine tissue samples were preserved in $1 \times$ PBS with $100 \mathrm{U} / \mathrm{mL}$ penicillin $\mathrm{G}$ and $100 \mu \mathrm{g} / \mathrm{mL}$ streptomycin and opened under laminar hood following strict aseptic measures. The sample was transferred to a $60 \mathrm{~mm}^{2}$ Petridish (BD Falcon, USA) with sterile $1 \times$ PBS in it. Uterus was cut through and rinsed with sterile PBS several times, and the inner surface was scrapped to obtain thin tissue pieces (Figure-1). As per general histology, canine endometrium contains stratum basalis (base layer containing secreting glands) and stratum functionalis (contains side population cell and endometrial progenitor cell). Then, the scrapped endometrium was separated and the aliquot was transferred to a conical tube. The collected endometrial tissue was subjected to enzymatic and mechanical digestion in two steps as per Park et al. [9]:

Step 1: The collected endometrium was treated with trypsin-EDTA (0.25\%) (trypsin (1×), 59429C, Safc, Bioscience USA) at $37^{\circ} \mathrm{C}$. Then, it was incubated in a $\mathrm{CO}_{2}$ incubator $\left(5 \% \mathrm{CO}_{2}, 0.4 \%\right.$ $\mathrm{O}_{2}$ ) New Brunswick Incubator Galaxy 170R) chamber for $5 \mathrm{~min}$. Then, the samples were taken out, washed with PBS, and the supernatant poured onto a separate $15 \mathrm{ml}$ conical tube (Figure-2).

Step 2: The sample was centrifuged at $1500 \mathrm{rpm}$ for $10 \mathrm{~min}$ at $37^{\circ} \mathrm{C}$ and the supernatant was discarded keeping the cell pellet in the test tube. Cells were passed through the cell strainer having $70 \mathrm{~mm}$ pore size (BD Bioscience, USA) and the flow through then transferred to a $15 \mathrm{ml}$ conical tube and frequently mixed by pipetting with Easypet (Eppendorf) (Figure-3). After mechanical separation, enzymatic digestion, washing, straining, and purification, the cells were seeded into two different basal culture media in four different ways such as: (a) $\mathrm{T}_{25}$ polystyrene culture flask containing RPMI $1640+10 \%$

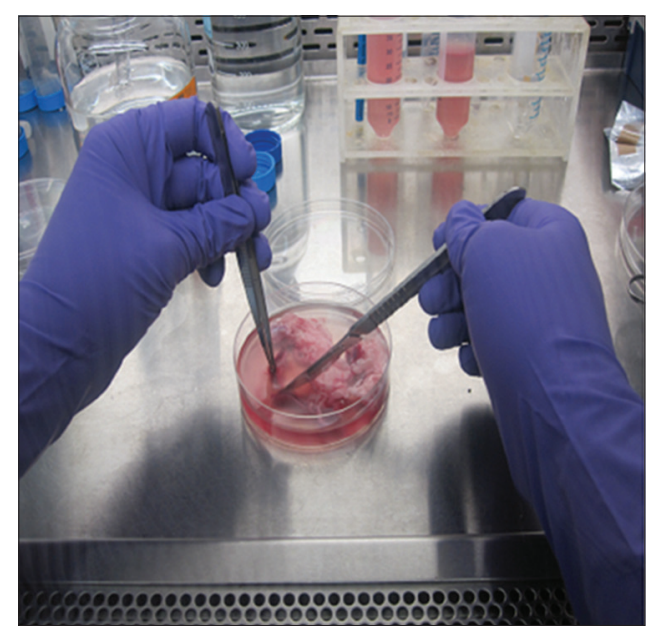

Figure-1: Scrapping of endometrium under sterile conditions. 
fetal bovine serum (FBS)+dexamethasone (maintained as reserve cells throughout the research work and preserved for future use), (b) $30 \mathrm{~mm}^{2}$ Petridish containing RPMI $1640+10 \%$ FBS+dexamethasone (used for RNA extraction on $14^{\text {th }}$ day), (c) $\mathrm{T}_{25}$ polystyrene cell culture flask containing Dulbecco's modified Eagle's medium (DMEM)+FBS $10 \%$ (used for induction media after 3 weeks of culturing), and (d) $30 \mathrm{~mm}^{2}$ Petridish containing DMEM+FBS10\% (used as a control for induction media). All the above processing was done in cell culture laboratory under laminar hood maintaining the strict guidelines of sterilization and also avoiding all sorts of contamination. The prepared cell suspension was incubated in a humidified atmosphere with $5 \% \mathrm{CO}_{2}$. The basal culture medium (RPMI $10 \%+$ dexamethasone and DMEM 10\%) was changed 2 times a week and passaged, once the cells reached $80-90 \%$ confluence.

\section{RNA extraction and quantification}

Total RNA was isolated according to the protocol outlined in the illustra ${ }^{\mathrm{TM}}$ RNAspin Mini RNA Isolation

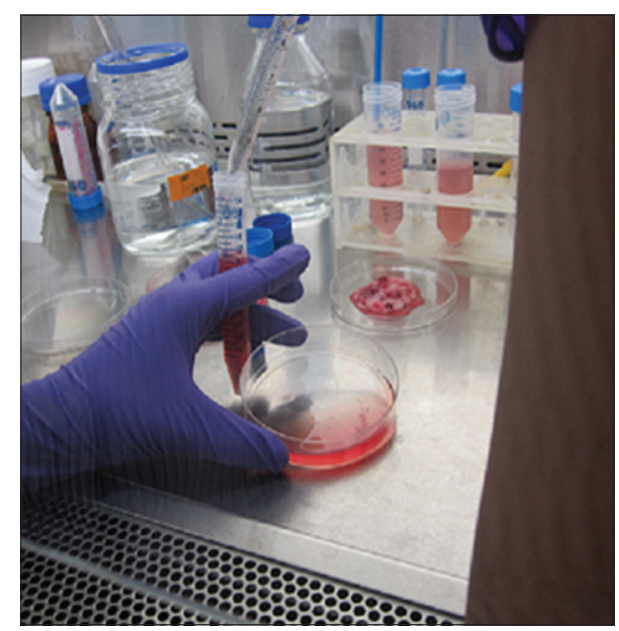

Figure-2: Trypsinization of sample.

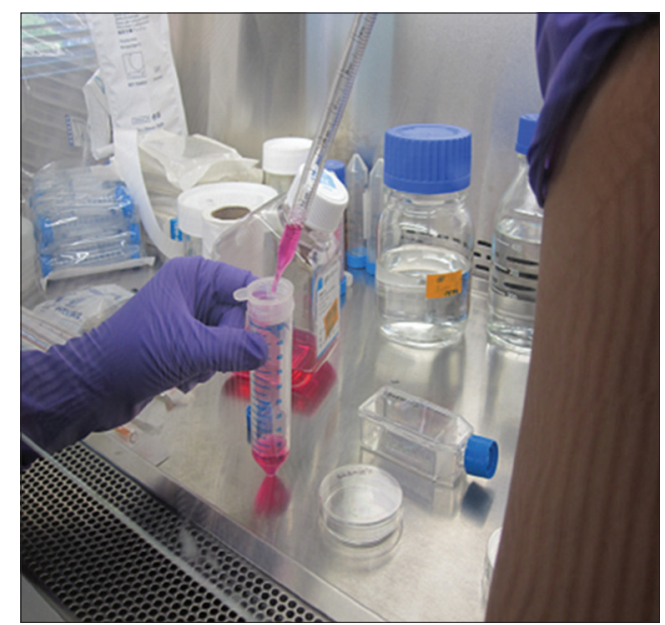

Figure-3: Passaging of trypsinized cells through cell strainer.
Kit (GE Healthcare, UK) following manufacturers guidelines. The RNA was eluted in $40 \mu$ RNase-free $\mathrm{H}_{2} \mathrm{O}$ or storage solution (Riboreserve ${ }^{T M}$ RNA storage solution, Amresco, Ohio) and incubated at room temperature for $10 \mathrm{~min}$ before being centrifuged at $11000 \times g$ for $1 \mathrm{~min}$. Eluted RNA was immediately placed on ice to prevent potential degradation. The eluted RNA was kept at $-20^{\circ} \mathrm{C}$ for short-term storage and RNA present was quantified through spectrophotometer (Eppendorf Biophotometer plus, Germany). Spectrophotometry was done and the assessed RNA quality with nucleotide : protein ratio $(260: 280)$ was within acceptable boundaries of 1.8 and $2.1 .5 \mu \mathrm{L}$ of freshly prepared uterine RNA were run on $1.5 \%$ agarose gel to check RNA band and quality. Band separation was first observed under UV transilluminator and then visualized using Molecular Imager ${ }^{\circledR}$ Chemi Doc $^{\text {TM }}$ XRS+Imaging System, BIO-RAD with Image $\mathrm{Lab}^{\mathrm{TM}}$ software Version 3.0.

Extracted RNA was reversed transcribed using the protocol outlined in the High-capacity cDNA Reverse Transcription Kit (Applied Biosystem, USA) as in Table-1. $20 \mu \mathrm{L}$ of reaction sample in polymerase chain reaction (PCR) tube was set in the thermal cycler with a setting of time and temperature as $25^{\circ} \mathrm{C}$ for $10 \mathrm{~min}, 37^{\circ} \mathrm{C}$ for $120 \mathrm{~min}, 85^{\circ} \mathrm{C}$ for $5 \mathrm{~min}$, and $4^{\circ} \mathrm{C}$ for $\infty$ time. The newly formed cDNA $(20 \mu \mathrm{L})$ was stored at $-20^{\circ} \mathrm{C}$.

\section{Primer design}

All the primers for the stem cell markers were selected from a published literature [8]. Before ordering, all the sequences were "BLAST" searched using NCBI database and following five primers were selected OCT4, SOX2, NANOG, KLF4, and GAPDH. This was done to make sure that all the primers are specific to only corresponding canine genes. Primers with corresponding sequences are shown in Table-2. All primers were ordered through MWG Eurofins. The concentration of the stock primers was $100 \mathrm{pmol} / \mu \mathrm{L}$. The stock solutions were further diluted to make 10 $\mathrm{pmol} / \mu \mathrm{L}$ working solution. Melting temperature for each primer was fixed $\left(\mathrm{OCT} 4-53^{\circ} \mathrm{C}\right.$, SOX $2-50^{\circ} \mathrm{C}$, NANOG $-55^{\circ} \mathrm{C}, \mathrm{KLF} 4-60^{\circ} \mathrm{C}$, and GAPDH $-55^{\circ} \mathrm{C}$ ).

\section{Reverse transcription-PCR (RT-PCR)}

The cDNA was amplified and cross-checked with the marker $\left(\mathrm{OCT}_{4}, \mathrm{SOX}_{2}\right.$, and GAPDH) in PCR.

Table-1: Preparation of cDNA Reverse transcription reaction.

\begin{tabular}{lcc}
\hline cDNA reagent mixture & Amount & Concentration \\
\hline $10 \times \mathrm{RT}$ buffer & $2 \mu \mathrm{L}$ & $1 \times$ \\
$25 \times \mathrm{dNTP}$ mix & $0.8 \mu \mathrm{L}$ & $4 \mathrm{mM}$ \\
$10 \times \mathrm{RT}$ Random Primer & $2 \mu \mathrm{L}$ & $1 \times$ \\
Multiscribe ${ }^{\mathrm{TM}}$ Reverse & $1 \mu \mathrm{L}$ & $2.5 \mu \mathrm{g} / \mu \mathrm{L}$ \\
Transcriptase & & \\
Nuclease-free water & $4.2 \mu \mathrm{L}$ & \\
Sample uterine RNA & $10 \mu \mathrm{L}$ & $3.2 \mu \mathrm{g}$ \\
Total & $20 \mu \mathrm{L}$ & \\
\hline
\end{tabular}


PCR Master Mixes were prepared for all canine experiments using Invitrogen PCR kit. PCR was run in PCR machine (Mastercycler ${ }^{\circledR}$ Pro, Eppendorf) with following PCR reaction mixture (Table-3). An initial denaturation step of $95^{\circ} \mathrm{C}$ for 5 min followed by 35 cycles of denaturation at $95^{\circ} \mathrm{C}$ for $1 \mathrm{~min}$, annealing at primer-specific temperatures $\left(\mathrm{OCT}_{4}-53^{\circ} \mathrm{C}\right.$, SOX2 - $50^{\circ} \mathrm{C}$, NANOG $-55^{\circ} \mathrm{C}, \mathrm{KLF} 4-60^{\circ} \mathrm{C}$, and GAPDH $-55^{\circ} \mathrm{C}$ ) for $1 \mathrm{~min}$, and extension at $72^{\circ} \mathrm{C}$ for $1 \mathrm{~min}$. The program was completed with a final extension step of $72^{\circ} \mathrm{C}$ for $10 \mathrm{~min}$. PCR product samples were stored at $4^{\circ} \mathrm{C}$ until analysis. Negative controls of RNA and water were run alongside to confirm the absence of genomic DNA contamination. PCR products were run on a $2 \%$ agarose gel and ethidium bromide. The samples were run through the gel using electrical current (Bio-Rad, UK) to create band separation and visualized using Molecular Imager ${ }^{\circledR}$ Chemi Doc ${ }^{\text {TM }}$ XRS+Imaging System, BIO RAD with Image $\mathrm{Lab}^{\mathrm{TM}}$ software Version 3.0.

\section{Osteogenesis}

The cells were plated at approximately at $1 \times 10^{4}$ cells per $\mathrm{T}_{25}$ polystyrene plate, incubated at $37^{\circ} \mathrm{C}, 5 \% \mathrm{CO}_{2}$ for $2-4$ days to allow growth of adherent cell layer. Dead cells and debris were discarded and the adherent cells washed with $1 \times$ PBS. The freshly prepared DMEM $10 \%$ media was added and the plate washed at every 2-3 days until the cells achieved $80-90 \%$ confluent, and usually, it occurs in $1-2$ weeks. Cells were further passaged using $0.25 \%$ trypsin-EDTA (Gibco, UK) to loosen cells and analyzed under a microscope for growth. Approximately $1 \times 10^{3}$ cells $/ \mathrm{cm}^{2}$ was replaced at each passage in tissue culture flasks. Control cell culture in RPMI $10 \%+$ dexamethasone media was grown and passaged in a similar manner. Morphology of cultured cells was studied on $7^{\text {th }}, 14^{\text {th }}$, and $21^{\text {st }}$ day in both DMEM $10 \%$ media and RPMI 10\%+dexamethasone. After 3 weeks and 5-6 passages, the cells in DMEM medium were split with trypsinization as follows. Media was pipetted out and discarded. $5 \mathrm{ml}$ of $0.05 \%$ trypsin were added to $\mathrm{T}_{25}$ polystyrene plate. Shacked and incubated in a $\mathrm{CO}_{2}$ incubator for $5 \mathrm{~min}$. $\mathrm{T}_{25}$ flask was taken out, pipetted 3-4 times and transferred to a $14 \mathrm{ml}$ Tarson tube, and centrifuged at $1500 \mathrm{rpm}$ for $5 \mathrm{~min}$ at room temperature. Then, the supernatant was discarded and pellets shook for 2-3 times.

$10 \mathrm{ml}$ of osteogenic differentiation medium containing ascorbic acid 2-phosphate $(50 \mathrm{mM})$, dexamethasone (100 nM), $b$-glycerophosphate $(10 \mathrm{mM})$ (Sigma-Aldrich, USA), and 10\% FBS in LG-DMEM was added, shacked, and the cells were then seeded into $\mathrm{T}_{25}$ polystyrene plate. Growth and differentiation of cultured cells were studied in control and the differentiation media for at least 3 weeks. The calcium deposition was detected by staining with Alizarin Red-S. Osteogenic differentiation media was discarded from $\mathrm{T}_{25}$ flasks. The cells were briefly washed with $1 \times$ PBS followed by fixation with ice-cold ethanol (70\%, Merck) for $1 \mathrm{~h}$ at $4^{\circ} \mathrm{C}$. Following Milli Q $\mathrm{H}_{2} \mathrm{O}$ rinsing, the cells were stained for $10 \mathrm{~min}$ with $50 \mathrm{mM}$ Alizarin Red-S in water ( $\mathrm{pH}$ 4.2) at room temperature. Cultures were then rinsed 5 times with Milli $\mathrm{Q} \mathrm{H}_{2} \mathrm{O}$ succeeded by a 15 min wash with $1 \times$ PBS to reduce non-specific staining following which the stained cells were photographed. Control cells did not stain red. This indicates that endometrial derived cells have multipotent differentiation capacity and self-renewal ability.

\section{RNA extraction from uterine tissue}

Uterine tissue sections collected during routine ovariohysterectomy procedures in liquid nitrogen, $1 \%$ PBS and RNA later were processed in the laboratory for isolation of RNA using TRIzol ${ }^{\circledR}$ extraction protocol involving homogenization, phase separation, and RNA isolation. Finally, the collected RNA pellet was resuspended in $50 \mu \mathrm{L}$ Riboreserve ${ }^{\mathrm{TM}}$ RNA storage solution (Amresco). The eluted RNA was quantified, and quality checked in a spectrophotometer with

Table-2: RT-PCR primer sequence.

\begin{tabular}{lllr}
\hline Name of gene & Sequence of primer (Forward) & Reverse & Amplicon size \\
\hline OCT4 & TCGTGAAGCCGACAAGGAGAAG & AGAACATGTTCTCCAGGTTGCCT & 387 \\
SOX2 & AACCCCAGATGCACAACTC & CGGGGCGGTATTATAATC & 162 \\
NANOG & CCTGCATCCTTGCCAATGTC & TCGGGCTGTCCTGAGTAAG & 409 \\
KLF4 & CCATGGGCCAAATACCCAC & ACTCTTCCACACACCATTCCGT & 98 \\
GAPDH & TATCAGTTGTGGATCTGACCTG & ACGC & 172 \\
\hline
\end{tabular}

Table-3: PCR for stem cell specific primer.

\begin{tabular}{|c|c|c|c|c|c|}
\hline Reagent & Sample1 ${ }^{\circ} \mathrm{CT} 4$ & Sample 2 So $\times 2$ & $\begin{array}{c}\text { Sample } 3 \\
\text { GAPDH }\end{array}$ & $\begin{array}{c}\text { Sample } 4+v e \\
\text { for GAPDH }\end{array}$ & -ve for GAPDH \\
\hline PCR Master Mix & $12.5 \mu \mathrm{L}$ & $12.5 \mu \mathrm{L}$ & $12.5 \mu \mathrm{L}$ & $12.5 \mu \mathrm{L}$ & $12.5 \mu \mathrm{L}$ \\
\hline CDNA & $\begin{array}{c}10 \mu \mathrm{L} \text { cell culture } \\
\text { cDNA }\end{array}$ & $\begin{array}{c}10 \mu \mathrm{L} \text { cell culture } \\
\text { cDNA }\end{array}$ & $\begin{array}{c}10 \mu \mathrm{L} \text { Cell culture } \\
\text { cDNA }\end{array}$ & $\begin{array}{c}10 \mu \mathrm{L} \text { Umbilicus } \\
\text { cDNA }\end{array}$ & - \\
\hline $\mathrm{F} / \mathrm{R}$ primer & $1 \mu \mathrm{L}$ OCT4 & $1 \mu \mathrm{L}$ SOX 2 & $1 \mu \mathrm{L}$ GAPDH & $1 \mu \mathrm{L}$ GAPDH & $1 \mu \mathrm{L}$ \\
\hline NFW & $1.5 \mu \mathrm{L}$ & $1.5 \mu \mathrm{L}$ & $1.5 \mu \mathrm{L}$ & $1.5 \mu \mathrm{L}$ & $11.5 \mu \mathrm{L}$ \\
\hline Total & $25 \mu \mathrm{L}$ & $25 \mu \mathrm{L}$ & $25 \mu \mathrm{L}$ & $25 \mu \mathrm{L}$ & $25 \mu \mathrm{L}$ \\
\hline
\end{tabular}

$\mathrm{NFW}=$ Nuclease-free water, $\mathrm{PCR}=$ Polymerase chain reaction 
sample diluted at 1:50. RNA quality was checked through 1.5\% Agarose gel electrophoresis by taking $5 \mu \mathrm{L}$ sample RNA with $1 \mu \mathrm{L}$ of dye in the well. Band separation was visualized by Molecular Imager using Image $\mathrm{Lab}^{\mathrm{TM}}$ software version 3.0 (Figure-4). The extracted RNA was reverse transcribed using the protocol outlined in the High-capacity cDNA Reverse Transcription Kit (Applied Biosystem, USA) and prepared cDNA stored at $-20^{\circ} \mathrm{C}$. Primers for stem cell marker (previously prepared) were used for RT-PCR.

\section{RT-PCR}

The cDNA was amplified and cross-checked with the marker in PCR in a sequential manner. PCR reaction mixtures were prepared for all canine experiments using the PCR kit (Invitrogen, USA) (Table-4).

The following protocol was found to be optimal for the reactions. An initial denaturation step of $95^{\circ} \mathrm{C}$ for $5 \mathrm{~min}$ was followed by 35 cycles of denaturation at $95^{\circ} \mathrm{C}$ for $1 \mathrm{~min}$, annealing at primer-specific temperatures for $1 \mathrm{~min}$, and extension at $72^{\circ} \mathrm{C}$ for $1 \mathrm{~min}$. The program was completed with a final extension step of $72^{\circ} \mathrm{C}$ for $10 \mathrm{~min}$. The samples were stored at $4^{\circ} \mathrm{C}$ until analysis and negative controls of RNA and water were run alongside to confirm the absence of genomic DNA contamination.

PCR products were run on a $2 \%$ agarose gel and $2 \%$ ethidium bromide. The samples were run in electrophoresis tank connected to a power pack (Bio-Rad, UK) to create band separation and analyze

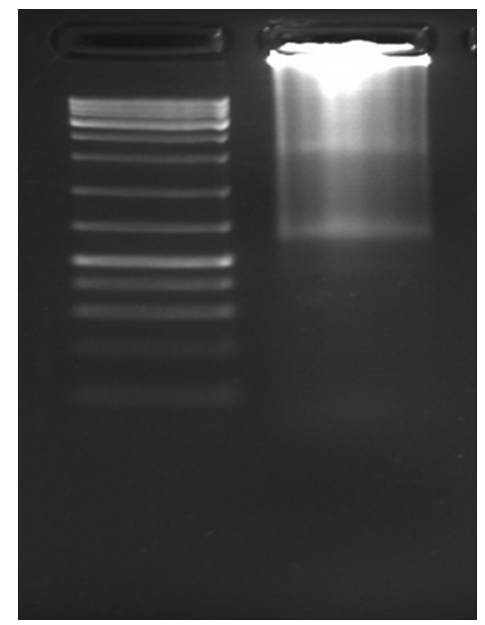

Figure-4: Agarose gel electrophoresis of uterine RNA.

Table-4: PCR reaction mixture with sample from umbilicus.

\begin{tabular}{lc}
\hline Reagent in PCR kit & Amount \\
\hline $10 \times \mathrm{RT}$ buffer & $5 \mu \mathrm{L}$ \\
$\mathrm{MgCl}_{2}$ & $1.5 \mu \mathrm{L}$ \\
dNTP & $1 \mu \mathrm{L}$ \\
GAPDH primer F/R & $2 \mu \mathrm{L}$ \\
Taq DNA polymerase enzyme & $0.5 \mu \mathrm{L}$ \\
CDNA from uterus/umbilicus & $10 \mu \mathrm{L}$ \\
DEPC-treated water & $30 \mu \mathrm{L}$ \\
Total & $50 \mu \mathrm{L}$ \\
\hline
\end{tabular}

$\mathrm{PCR}=$ Polymerase chain reaction with Molecular Imger ${ }^{\circledR}$ Chemi Doc ${ }^{\text {TM }}$ XRS+Imaging System.

\section{RNA extraction from umbilical cord matrix (positive} control)

Umbilicus which was collected in liquid nitrogen and kept at $-80^{\circ} \mathrm{C}$ was taken out, triturated with pestle and mortar. RNA extraction was done the following guidelines of TRIzol ${ }^{\circledR}$ extraction protocol for RNA extraction from the tissue sample. Four samples of umbilicus were homogenized (using power homogenizer) separately in $1 \mathrm{ml}$ of TRIzol and processed in the same manner as RNA was extracted from the uterus. This was followed by phase separation, RNA precipitation, washing, and resuspension, or elution with Riboreserve RNA storage solution. $50 \mu \mathrm{L}$ RNA was prepared from each of four umbilical samples and stored at $-80^{\circ} \mathrm{C} .2 \mu \mathrm{L}$ of the RNA from each sample was utilized for quantitative estimation in a spectrophotometer (Biophotometer plus, Germany) with 1:50 dilution ratio. The RNA quality was checked through $1.5 \%$ agarose gel electrophoresis by taking $5 \mu \mathrm{L}$ RNA from each sample with $1 \mu \mathrm{L}$ of dye in each of four wells. Band separation was analyzed for four RNA sample. The procedure for cDNA synthesis was done following High-capacity cDNA Reverse Transcription Kit as described previously and RT-PCR amplification of all the five primers done.

\section{RT-PCR analysis}

The cDNA synthesis was further amplified in PCR system using five primers (OCT4, SOX2, NANOG, KLF4, and GAPDH), and the product was analyzed in Gel Doc Molecular Imager.

\section{Results}

\section{Tissue sectioning and cryostat picture}

Uterine mass which was collected in the liquid nitrogen and stored at $-80^{\circ} \mathrm{C}$ was sectioned in the cryostat and stained with $\mathrm{H}$ and $\mathrm{E}$ following the protocol of $\mathrm{H}$ and $\mathrm{E}$ staining protocol of frozen section. Photographs were taken before and after scrapping to evaluate the portion of the uterus used for cell culture, and it was seen that the innermost endometrium layer was scrapped and utilized in the cell culture development.

\section{Primary culture of canine endometrium-derived MSCs}

Canine uterus which was collected during routine ovariohysterectomy procedure in $1 \times$ PBS was used for the development of primary cell culture on the same day. The cells were seeded in a new flask when they reach $80-90 \%$ confluency. The medium was changed weekly twice during which the dead cells and debris get discarded. Non-adherent cells (non-mesenchymal) floated freely and were washed out along with the debris. Photomicrographs were taken at regular intervals on $7^{\text {th }}, 14^{\text {th }}$, and $21^{\text {st }}$ (Figures-5a-d and 6a-c) days to have a clear outline of changing the shape of the monolayer at the weekly interval and prolificacy of the cell lines. 
Some of the cells also developed colonies indicating colony-forming unit which is the characteristic of mesenchymal stem cells. The canine endometrial-derived cells displayed spindle-shaped morphology which is a characteristic of MSCs and was adherent to the plastic culture surface (plasticity). MSCs adhered naturally to tissue culture plastic over 2-4 days. It was observed that canine MSCs typically senescence between passage 4 and 6 , at which point the cells increased in size and the spindle projections would fatten indicating their maturity. Of two different culture medium, it was seen that cells grown in medium supplemented with dexamethasone showed a number of colonies than DMEM medium.

\section{Osteogenesis}

$\mathrm{T}_{25}$ culture flask having basal culture medium as DMEM+FBS $10 \%$ grown for 3 weeks was changed to

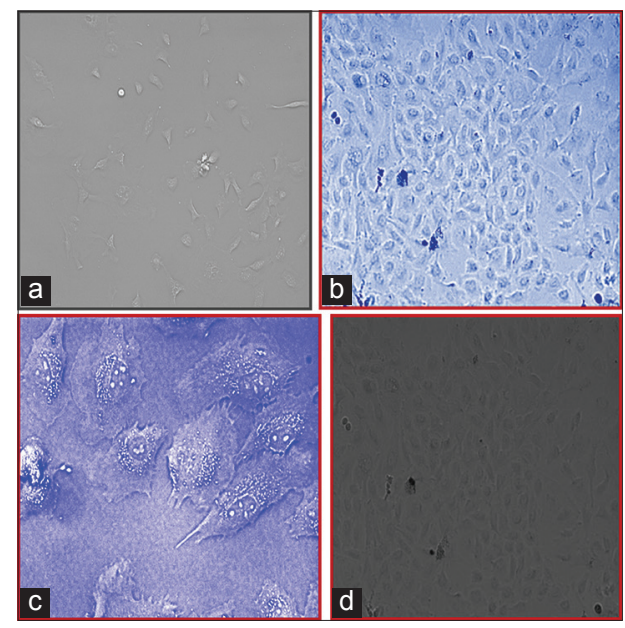

Figure-5: (a) Photomicrograph of cells in Dulbecco's modified Eagle's medium (DMEM) on $7^{\text {th }}$ day, $10 \times$. (b) Photomicrograph of cells in DMEM on $14^{\text {th }}$ day, $10 \times$. (c) Photomicrograph of cells in DMEM on $14^{\text {th }}$ day, $40 \times$. (d) Photomicrograph of cells in DMEM on $21^{\text {st }}$ day $10 \times$.

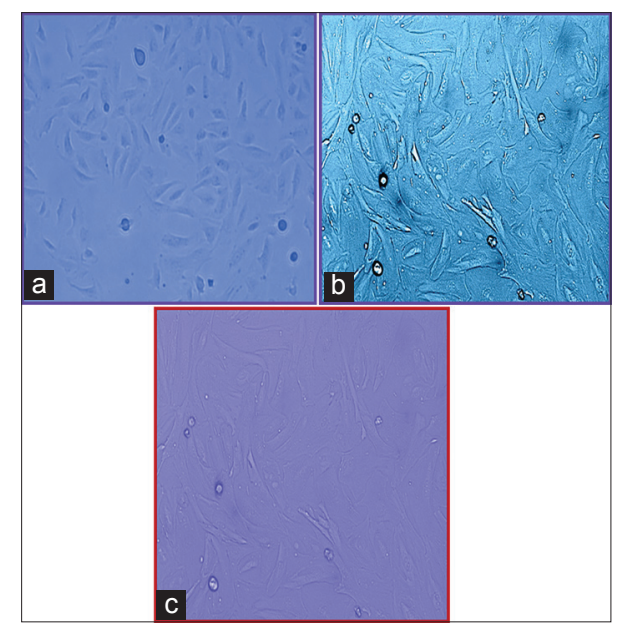

Figure-6: (a) Photomicrograph of cells in RPMI+dexamethasone on $7^{\text {th }}$ day, $10 \times$. (b) Photomicrograph of cells in RPMI+dexamethasone on $14^{\text {th }}$ day, $10 \times$. (c) Photomicrograph of cells in RPMI+dexamethasone on $21^{\text {st }}$ day, $10 \times$, and on $14^{\text {th }}$ day, $10 \times$. osteogenic differentiation media, and the cells were cultured for at least 3 more weeks in osteogenic differentiation media. While growing in the induction media, the cells show some morphological differentiating feature and cells also proliferate in this induction media. There was thrice change in induction media before being stained for calcium crystal deposits. Alizarin Red-S staining, which positively stains calcium depositions, was used to detect differentiation. The basal culture medium containing DMEM+FBS $10 \%$ was used as a control condition. Under differentiation conditions, there was strong, positive Alizarin Red-S staining (Figure-7a-c). However, all the colonies present on the same disc were not positively stained, but negative staining was observed under control condition (Figure-8).

\section{Proliferation ability}

Cells in the $\mathrm{T}_{25}$ culture flask having RPMI $1640+10 \%$ FBS+dexamethasone which was maintained in the same culture condition showed a decrease

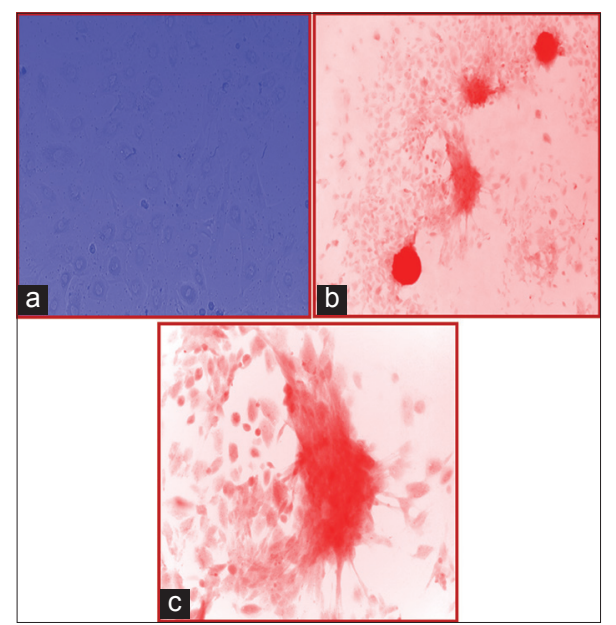

Figure-7: (a) Photomicrograph of cells in osteogenic differentiation media $7^{\text {th }}$ day $(10 \times)$. (b) Photomicrograph of cells grown in ODM stained with Alizarin Red-S staining $(10 \times)$. (c) Photomicrograph of cells grown in ODM stained with Alizarin Red-S staining $(40 \times)$.

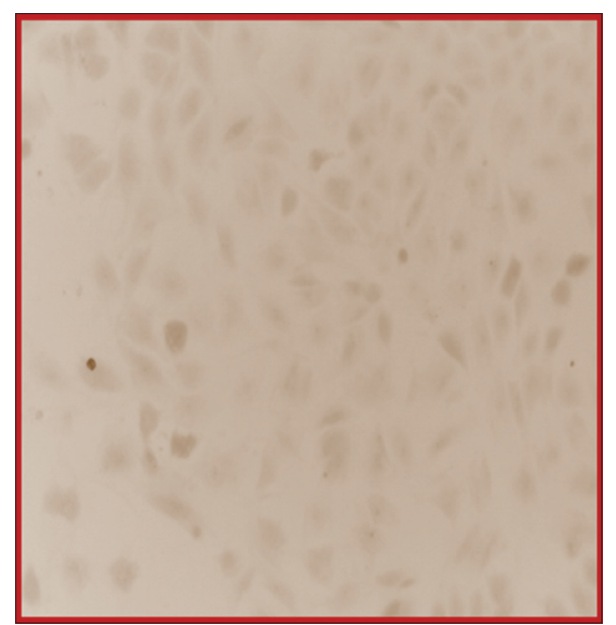

Figure-8: Photomicrograph of cells grown in ODM stained negatively with Alizarin Red-S staining (10x). 
in the proliferation capacity as the cells were passaged from 3 to 10 .

\section{RNA extraction from cell monolayer}

The cells grown in $30 \mathrm{~mm}^{2}$ Petri dish containing basal culture medium RPMI $1640+10 \%$ FBS+dexamethasone was selected for RNA extraction on the $14^{\text {th }}$ day. The RNA was extracted from the monolayer cells following the illustra ${ }^{\mathrm{TM}}$ RNAspin Mini RNA Isolation Kit (GE healthcare) guidelines. A $50 \mu \mathrm{L}$ of RNA was prepared and stored at $-80^{\circ} \mathrm{C}$ for further use. $2 \mu \mathrm{L}$ of isolated RNA was utilized for quantification using a spectrophotometer and the reading was 1.42 indicating the average quality of RNA. $5 \mu \mathrm{L}$ of freshly prepared uterine RNA was run on a $1.5 \%$ agarose gel to check RNA band and quality. Band separation was analyzed with UV transilluminator and then visualized using Molecular Imager ${ }^{\circledR}$. A faint RNA band was observed in the gel.

\section{cDNA synthesis and RT-PCR analysis}

A $10 \mu \mathrm{L}$ of endometrium RNA was utilized for preparation of cDNA reaction mixture which then processed in the thermal cycler to form $20 \mu \mathrm{L}$ of cDNA following the protocol of High-capacity cDNA Reverse Transcription Kit. Then, $20 \mu \mathrm{L}$ cDNA was diluted with $80 \mu \mathrm{L}$ of DEPC treated water to prepare $100 \mu \mathrm{L}$ of cDNA with a final concentration of $500 \mathrm{ng} / \mu \mathrm{L}$. PCR was run in PCR machine with $10 \mu \mathrm{L}$ of sample cDNA in a PCR reaction tube (Axygen, USA). At first, GAPDH was amplified at $55^{\circ} \mathrm{C}$ with the umbilicus as a positive control. Band separation was observed in Molecular Imager ${ }^{\circledR}$. Bands appear for GAPDH at $172 \mathrm{bp}$. Then, PCR was done for other two Primers (OCT4, SOX2) (Figure-9). In this, SOX2 expresses negatively.

\section{cDNA synthesis and RT-PCR analysis of stem cell primer of umbilical RNA}

$50 \mu \mathrm{L}$ of umbilical RNA prepared from four samples were centrifuged and the supernatant discarded. Pellet was again eluted to $50 \mu \mathrm{L}$ of RNA by mixing with Riboreserve ${ }^{\mathrm{TM}} \mathrm{RNA}$ storage solution. The cDNA was prepared following High-capacity cDNA Reverse Transcription Kit (Applied Biosystem, USA) protocol. Then, cDNA was amplified by PCR machine.

PCR was run first with GAPDH $\left(55^{\circ} \mathrm{C}\right)$ only which results in a positive expression pattern as distinct bands were seen in agarose gel. Then, primer amplification was done for OCT4, SOX2, NANOG, and $\mathrm{KLF} 4$ with annealing temperature set at $53^{\circ} \mathrm{C}$, $50^{\circ} \mathrm{C}, 55^{\circ} \mathrm{C}$, and $60^{\circ} \mathrm{C}$, respectively. Positive expression pattern was observed for OCT4 (387 bp), SOX2, and GAPDH (172 bp). The NANOG and KLF4 express negatively as no bands were seen in their respective well (Figure-10).

\section{Discussion}

The canine uterus consists of perimetrium, myometrium, and endometrium. The perimetrium is the outermost serosal or connective tissue layer of the

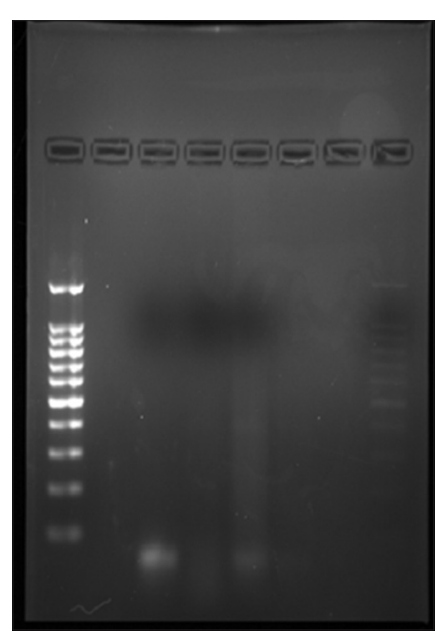

Figure-9: Agarose gel electrophoresis of OCT4 in culture cell, negative for SOX2.

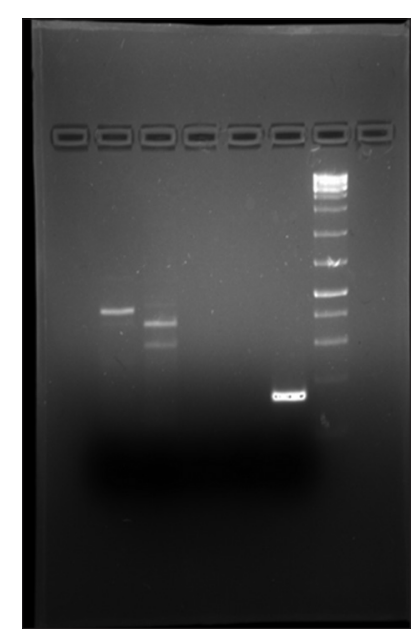

Figure-10: Agarose gel electrophoresis GAPDH, OCT4, SOX2, KLF4, and NANOG of umbilicus RNA.

uterus which holds it in position within the pelvic cavity. The myometrium is the muscular layer supplying blood and lymph to all other layers. The particular importance of the study was the innermost endometrium consisting of the superficial functional zone and thin deep basal zone. The superficial zones degenerate partially or fully in each reproductive/estrus cycle, whereas the basal zone persists throughout the cycle and replaces the upper layer when lost. Thus, the canine endometrium can be defined as a cyclically regenerating mucosal tissue comprising of glands and extensive vascularized stroma.

Studies by Gargett et al. [17] and other scientist have shown that both human and murine endometrium may contain adult stem cells such as clonogenic cells [18], side population cells [19,20], and some cells that can differentiate into osteocytes, adipocytes, and chondrocytes [21] in human endometrium. Gargett et al. [17] showed in their study about the presence of epithelial progenitor cells having MSC like properties.

The fact that human endometrium contains stem cells in the basal layer and stroma while canine endometrium contains cells in the basal zone which restores 
cells of the superficial zone at the time of need which encourages us to hypothesize that the "basal layer of canine endometrium contains cells which may have the characteristic of stem cell-like properties."

Various researchers and workers have isolated stem cells from diversified organ starting from blastocyst of embryo (for ESCs), umbilical blood to adult tissue such as bone marrow, adipose tissue, liver, heart, skin, intestine, lungs, deciduous teeth, and also birth associated tissue such as umbilical cord blood and placenta (amnion, chorion, and allantois) (for MSCs). However, the amount of stem cells that have been isolated from these tissues is not promising. Furthermore, canine stem cells have been studied for use in cell therapy in few cases $[9,22,23]$ although the amniotic membrane has clinical applications in covering wounds, burn lesions, and ocular surface reconstructions [24]. Therefore, a constant and established source of stem cells is the need of the day which can only be achieved through collection, separation, purification, and proliferation of cells derived from endometrium obtained anytime through routine ovariohysterectomy procedures carried out in the Animal Birth Control Program.

In the present study, the photographs were recorded during cryostat section of three layers of uterus through $\mathrm{H}$ and $\mathrm{E}$ straining, and then after scrapping, the endometrium through $\mathrm{H}$ and $\mathrm{E}$ staining (only perimetrium and myometrium were seen) gives the information that the scrapped cells cultured were actually from the basal and superficial layer of endometrium and not from other two layers.

Further, the primary cell culture from these scrapped cells was developed and maintained up to at least ten passages in the basal medium. The cells were isolated and cultured from three out of four different uterine samples (the rate of success of propagation was $75 \%$ ). All the isolated cells showed very similar cell morphology and ability to be subcultured. Although the initial cell culture consisted of both fibroblastoid and non-fibroblastoid cell types, only the fibroblastoid population remained after enzymatic digestion and passage. Therefore, the endometrium-derived stem cells can be successfully isolated and expanded in vitro.

During maintenance and passaging of cells, it was learned that these cells adhered to the cell culture flask in 2-3 days and growth takes place exponentially indicating prolificacy characteristic (one of the functional properties) of mesenchymal stem cells. Flasks which were subjected to osteogenic differentiation media other than basal culture condition showed a good level of induction to osteogenesis. To confirm the differentiation ability in osteogenic medium, the flask containing cell monolayer was stained with Alizarin Red-S (pH 4.2) and showed strong positive reaction, indicating differentiation into one or more lineage (another functional property of stem cells in culture condition).
With the demonstration of functional properties in vitro, the properties of these cells have been further evaluated by isolating RNA from one of the Petri dish through the guided protocol and subsequently synthesizing the cDNA and RT-PCR analysis for amplification of five publicized primer (OCT4, SOX2, NANOG, KLF4, and GAPDH). It adds to our evaluation that OCT4, SOX2, and GAPDH which were considered to be primary embryonic stem cell markers and expressed by almost all adult stem cells of the body were also expressed by these cell types. NANOG and KLF4 were found negatively expressed as for other MSCs. This suggests that the endometrium-derived stem cells are very primitive cells. If this belief is correct, then the renewal and differentiation capacity of endometrium stem cells are more extensive than ASCs. Our morphology and differentiation study indicated the presence of stem cells in uterine cells harvested from the fresh canine uterus; however, we failed to detect any stem cell marker through normal PCR method and this might be due to the following reasons. (a) In the collected uterine endometrium, the number of stem cells might be very less compared to the umbilicus. (b) The technique might not be very sensitive to detect low abundance cells. (c) In the cultured cells at the time of RNA isolation, many cells might have already differentiated. This is also supported by the fact that our Alizarin Red-S staining failed to stain all the cells in the culture dish.

In this work, the umbilicus was taken as a positive control for expression of these stem cell marker based on the report of Lee et al. [6] and compared with endometrial-derived RNA, PCR product, and amplified primer with its corresponding counterpart.

\section{Conclusion}

These results showed that the isolation of stem cells from canine endometrium expresses the characteristic of MSCs and self-renewal ability. The presence of stem cells in the endometrium could have tremendous implications. Although this is a basic and preliminary study of its types, the initial data on the differentiation capabilities of endometrium derived stem cells are promising and there may be important therapeutic uses for these cells. Along with this, the ease of accessibility, lack of ethical concerns, and abundant availability of canine-En-MSCs, it shows an attractive and alternative source of adult stem cells for further research and clinical applications.

\section{Authors' Contributions}

AKS prepared the study design and carried out research under the supervision of JKD and SN. The manuscript was drafted by AKS and revised by JKD. All authors read and approved the final manuscript.

\section{Acknowledgments}

The molecular part of the study, i.e., the isolation, characterization, and histopathology were conducted 
in the Department of Translational Research, Tumor Microenvironment and Animal Models Laboratory under the guidance of Dr. Santibhusan Senapati, Scientist-D in the Institute of Life Science. The authors cordially thank Director, AH and VS for allowing him to collect samples from Veterinary Polyclinic, Saheed Nagar.

\section{Competing Interests} interests.

The authors declare that they have no competing

\section{References}

1. Wagers, A.J. and Weissman, I.L. (2004) Plasticity of adult stem cells. Cell, 116: 639-648.

2. Ai, J., Ebrahimi, S., Khoshzaban, A., Jafarzadeh Kashi T.S. and Mehrabani, D. (2012) Tissue engineering using human mineralized bone xenograft and bone marrow mesenchymal stem cells allograft in healing of tibial fracture of experimental rabbit model. Iran. Red Crescent Med. J., 14: 96-103.

3. Hosseinkhani, M., Mehrabani, D., Karimfar, M.H., Bakhtiyari, S., Manafi, A. and Shirazi, R. (2014) Tissue engineered scaffolds in regenerative medicine. World $J$. Plast Surg., 3: 3-7.

4. Fayazi, M., Salehnia, M. and Ziaei, S. (2015) Differentiation of human CD146-positive endometrial stem cells to adipogenic-, osteogenic-, neural progenitor-, and gliallike cells. In vitro Cell. Dev. Biol. Anim., 51(4): 408-414.

5. Friedenstein, A.J., Chailakhyan, R.K. and Gerasimov, U.V. (1987) Bone marrow osteogenic stem cells: In vitro cultivation and transplantation in diffusion chambers. Cell Tissue Kinet., 20: 263-272.

6. Lee, O.K., Kuo, T.K., Chen, W.M., Lee, K.D., Hsieh, S.L and Chen, T.H. (2004) Isolation of multipotent mesenchymal stem cells from umbilical cord blood. Blood, 103: 1669-1675.

7. Rada, T., Reis, R.L. and Gomes, M.E. (2011) Distinct stem cells subpopulations isolated from human adipose tissue exhibit different chondrogenic and osteogenic differentiation potential. Stem Cell Rev. Rep., 7: 64-76.

8. Perin, L., Giuliani, S., Jin, D., Sedrakyan, S., Carraro, G., Habibian, R., Warburton, D., Atala, A. and De Filippo, R.E. (2007) Renal differentiation of amniotic fluid stem cells. Cell Prolif., 40: 936-948.

9. Park, S.B., Seo, M.S., Kim, H.S. and Kang, K.S. (2012) Isolation and characterization of canine amniotic membrane-derived multipotent stem cells. PLoS One, 7(9), e44693.

10. Mead, L.E., Prater, D., Yoder, M.C. and Ingram, D.A. (2008) Isolation and characterization of endothelial progenitor cells from human blood. Curr. Protoc. Stem Cell Biol., 2(1):1-27.

11. Mehrabani, D., Rahmanifar, F., Mellinejad, M., Tamadon, A.,
Dianatpour, M., Zare, S. and Ghobadi, F. (2015) Isolation, culture, characterization, and adipogenic differentiation of heifer endometrial mesenchymal stem cells. Comp. Clin. Pathol., 24(5): 1159-1164.

12. Tsuji, S., Yoshimoto, M., Takahashi, K., Noda, Y., Nakahata, T. and Heike, T. (2008) Side population cells contribute to the genesis of human endometrium. Fertil. Steril., 90: 1528-1537.

13. Cervello, I., Martinez-Conejero, J.A., Horcajadas, J.A., Pellicer, A. and Simmon, C. (2007) Identification, characterization and co-localization of label retaining cell population in mouse endometrium with typical undifferentiated markers. Hum. Reprod., 22: 45-51.

14. Johnson, G.A., Burghardt, R.C., Newton, G.R., Bazer, F.W. and Spencer, T.E. (1999) Development and characterization of immortalized ovine endometrial cell lines. Biol. Reprod., 61: 1324-1330.

15. Cesaris, V.D., Grolli, S., Bresciani, C., Conti, V., Basini, G., Parmigiani, E. and Bigliardi, E. (2016) Isolation, proliferation and characterization of endometrial canine stem cells. Reprod. Domest. Anim., 52: 235-242.

16. Rink, B., Amilon, K.R., Esteves, C.L., French, H.M., Watson, E., Aurich, E. and Donadeu, F.X. (2017) Isolation and characterization of equine endometrial mesenchymal stromal cells. Stem Cell Res. Ther., 8: 166.

17. Gargett, C.E., Schwab, K.E., Zillwood, R.M., Nguyen, R.T. and $\mathrm{Wu}, \mathrm{D}$. (2009) Isolation and culture of epithelial progenitors and mesenchymal stem cells from human endometrium. Biol Reprod., 80: 1136-1145.

18. Patel, A.N., Park, E., Kuzman, M., Benetti, F., Silva, J.F. and Allickson, J.G. (2008) Multipotent menstrual blood stromal stem cells: Isolation, characterization, and differentiation. Cell Transplant., 17: 303-311.

19. Fayazi, M., Salehnia, M. and Ziaei, S. (2016) Characteristics of human endometrial stem cells in tissue and isolated cultured cells: An immunohistochemical aspect. Iran. Biomed. J., 20(2): 109-116.

20. Seo, M.S., Jeong, Y.H., Park, J.R., Park, S.B., Rho, K.H., Kim, H.S., Yu, K.R., Lee, S.H., Jung, J.W., Lee, Y.S. and Kang, K.S. (2009) Isolation and characterization of canine umbilical cord blood-derived mesenchymal stem cells. $J$. Vet. Sci., 10: 181-187.

21. Dominici, M., Le, B.K., Mueller, I., Slaper-Cortenbach, I., Marini, F., Krause, D., Deans, R., Keating, A., Prockop, D. and Horwitz, E. (2006) Minimal criteria for defining multipotent mesenchymal stromal cells. The International Society for Cellular Therapy position statement. Cytotherapy, 8: 315-317.

22. Mahla, R.S. (2016) stem cells applications in regenerative medicine and disease therapeuticsm. Int. J. Cell Biol., 2016: Article ID: 6940283, 24.

23. Mead, B., Berry, M., Logan, A., Scott, R.A.H., Leadbeater, W. and Scheven. B.A. (2015) Stem cell treatment of degenerative eye disease. Stem Cell Res., 14: 243-257.

24. Verdi, J., Tan, A., Shoae-Hassani, A. and Seifalian, A.M. (2014) Endometrial stem cells in regenerative medicine. $J$. Biol. Eng., 8: 20. 